\title{
Royal Images and Sacred Elements in Norman-Swabian and Angevin-Aragonese Kingdom of Sicily ${ }^{1}$ Imágenes regias y elementos sagrados en el reino normando-suevo y angevino-aragonés de Sicilia
}

\author{
Mirko VAGNONI \\ Universität Kassel \\ mirkovagnoni@libero.it
}

Recibido: 30/10/2013

Aceptado: 24/11/2013

\begin{abstract}
This paper analyses the royal images and the sacred elements; or rather, it studies the pictures of the kings of Sicily in Norman-Swabian and Angevin-Aragonese period (11301343) produced inside the court with an official intent, and it examines their meaning regarding the royal sacrality of the king there represented: in other words, the relationship of the sovereign with the sacred element. In this way, it will achieve, regarding this matter, a different position in comparison with the previous interpretations given by historiography.
\end{abstract}

Key words: Royal iconography, royal sacrality, representation of power, kingship, kingdom of Sicily (1130-1343).

Resumen: Este artículo analiza las imágenes reales y los elementos sagrados, o mejor dicho, estudia las imágenes de los reyes de Sicilia en el período normando-suevo y angevino-aragonés (1130-1343) producidas en la corte con una intención oficial, y examina su significado en relación con la sacralidad regia del monarca representado en ellas: en otros términos, la relación del soberano con el elemento sagrado. De este modo, el artículo adquirirá sobre este tema una posición diferente en comparación con las anteriores interpretaciones dadas por la historiografía.

Palabras clave: Iconografía real, sacralidad regia, representación del poder, monarquía, reino de Sicilia (1130-1343).

Sumario: 1.Introduction. 2. Normans. 3. Robert of Anjou. 4. Frederick II. 5. Conclusions. Bibliography.

$$
* * * * *
$$

\section{Introduction}

In 1917 Rudolf Otto described sacrality ("Das Heilige") as an element of absolute power for its possessor. ${ }^{2}$ In this sense sacrality can be considered an important component of the leader described by Otto's contemporaries, Sigmund

\footnotetext{
${ }^{1}$ This is the text of my lecture at El componente árabe en el arte de Sicilia. Las cuestiones sicilianas: Primer seminario internacional sobre la Sicilia árabe, Instituto de Lenguas y Culturas del Mediterráneo y Oriente Próximo, CSIC, Madrid, on June 10, 2013. I thank Ms. Hailey LaVoy for the revision of my English text.

${ }^{2}$ OTTо, Rudolf, 1966, Il sacro. L'irrazionale nell'idea del divino e la sua relazione al razionale, It. ed., Milano, Feltrinelli (but original ed. Breslau, 1917), 192 p.
} 
Freud and Max Weber. ${ }^{3}$ It is interesting that some of the most seminal studies on medieval sacrality and leadership were written precisely in these years, and they have considered royal sacrality as a propagandistic element exploited by kings in order to enhance their own power (Marc Bloch, Ernst Kantorowicz, Percy Ernst Schramm). ${ }^{4}$ However, in 1952 Wilfred Bion and in 1969 Norbert Elias overturned this interpretation of leader, suggesting that the leader does not impose himself on society, but rather reflects it. ${ }^{5}$

From this perspective perhaps the propagandistic meaning given to royal sacrality is no longer quite so obvious. But, if it appears clear that royal sacrality is a historical phenomenon and a cultural product of one society (Glauco Maria Cantarella), ${ }^{6}$ it is nevertheless very difficult to give a general definition of its meaning. In other words, I think that royal sacrality can have different functions in different contexts, and historians have to verify -in every single case- its specific meaning without limiting it within a generic definition. Unfortunately, from my own research, I can say that the documents produced in the kingdom of Sicily rarely refer to royal sacrality and, when they do, it is always in the form of very few references inserted into a context that is, in general, dedicated to other aspects. Thus, the function of royal sacrality is not usually explicit in these texts, and it is quite difficult to give a general definition of it.

For this reason I have decided to analyse this aspect of the kingdom of Sicily by only approaching royal sacrality as a simple way to represent power or rather, with a point of view concerning the cultural history and specifically the history of ideas. In other words, my work is about how the relationships between king and

${ }^{3}$ FREUD, Sigmund, 2013, Psicologie delle masse e analisi dell'io, It. ed., ed. by D. Tarizzo, Torino, Einaudi (but original ed. Leipzig, 1921), LI-92 p. WEBER, Max, 1961, Economia e società, It. ed., intr. of P. Rossi, Milano, Edizioni di Comunità (but original ed. Tübingen, 1922), 2 vol.

4 BLOCH, Marc, 1989, I re taumaturghi. Studi sul carattere sovrannaturale attribuito alla potenza dei re particolarmente in Francia e in Inghilterra, intr. of J. Le Goff, Ricordo di Marc Bloch of L. Febvre, It. ed., Torino, Einaudi (but original ed. Paris, 1924), LXVIII-424 p. KANTOROWICZ, Ernst, 2000, Federico II imperatore, It. ed., Milano, Garzanti (but original ed. Berlin, 1927-1931), 791 p. SCHRAMM, Percy Ernst, 1928, Die deutschen Kaiser und Könige in Bildern ihrer Zeit. Bis zur Mitte 12. Jahrhunderts (751-1152), Berlin-Leipzig, Teubner, 2 vol. IDEM, 1929, Kaiser, Rom und Renovatio. Studien und Texte zur Geschichte des römischen Erneuerungsgedankens vom Ende des karolingischen Reiches bis zum Investiturstreit, Leipzig, Wissenschaftliche Buchgesellschaft, 490 p.

${ }^{5}$ BION, Wilfred Ruprecht, 1971, "Dinamiche di gruppo", now in IDEM, Esperienze nei gruppi e altri saggi, It. ed., Roma, Armando (but original ed. London, 1961), p. 149-202. ELIAS, Norbert, 1980, La società di corte, It. ed., intr. of A. Tenenti, Bologna, il Mulino (but original ed. Darmstadt-Neuwied, 1969), 382 p.

${ }^{6}$ CAntarella, Glauco Maria, 2002, "Le basi concettuali del potere", in Per me reges regnant. La regalità sacra nell'Europa medievale, ed. by F. Cardini, and M. Saltarelli, Rimini-Siena, Cantagalli-il Cerchio, p. 193-208. IDEM, 2003, "Qualche idea sulla sacralità regale alla luce delle recenti ricerche: itinerari e interrogativi”, Studi Medievali, s. III, n 44, p. 911-927. IDEM, 2005, "Divagazioni preliminari", in "C'era una volta un re... ". Aspetti e momenti della regalità, ed. by G. Isabella, Proceedings of the Seminar of Bologna, Bologna, December 17-18, 2003, Bologna, CLUEB, p. 9-24. 
sacred elements (that is to say, divine and religious authorities) are described in the sources produced in the king's own court and realised from an official point of view. Obviously, considering that every source must be analysed in view of its context, this last aspect is particularly important because only these types of sources can offer interesting information for my purposes.

That having been said, I can introduce the general topic of my research. In the last years I have analysed royal sacrality in the kingdom of Sicily by comparing both iconographic and written sources. In particular, I illustrate some considerations concerning sacred elements in royal images of Norman-Swabian and Angevin-Aragonese period, or more precisely between the foundation of the kingdom by Roger II in 1130 to the death of Robert the Wise in 1343, looking through the rich material evidence of mosaics, paintings, sculptures, miniatures, coins and seals and between scenes of coronations or blessings by God and Christ as well as the presences or the absences of pictures of saints, angels or religious symbols.

Particularly, my intent is to verify whether in all these images we can find explicit elements regarding those ideological concepts that historiography about kingdom of Sicily has often proposed for its rulers, that is the king as a Deo coronatus, rex et sacerdos, christomimetes and imago Dei. ${ }^{7}$ I wish to answer the following question: were these concepts really present in the official representation of the kings of Sicily?

First of all, I would immediately like to say that among the existing images of the kings of Sicily, we can find interesting elements in this sense in only a few cases. Therefore, I think that it is very important to underline that royal sacrality is not the primary aspect of the representation of these rulers, and, moreover, it is not absolutely constant for the period that I have analysed. For example, while it is present during the Norman period, it disappears in the following years, only to come back during the reign of Robert of Anjou (though in a very different manner).

\section{Normans}

\footnotetext{
${ }^{7}$ KAntorowicz, 2000. Kitzinger, Ernst, 1950, "On the Portrait of Roger II in the Martorana in Palermo", Proporzioni. Studi di Storia dell'Arte, n 3, p. 30-35. SCHALLER, Hans-Martin, 1974, "Die Kaiseridee Friedrichs II.", in Probleme um Friedrich II., ed. by J. Fleckenstein, Sigmaringen, Thorbecke, p. 109-134. CANTARELlA, Glauco Maria, 1988, La Sicilia e i Normanni. Le fonti del mito, intr. of O. Capitani, Bologna, Pàtron, 197 p. BoYER, Jean-Paul, 1994, "La «foi monarchique»: royaume de Sicile et Provence (mi-XIII - mi-XIV siècle)", in Le forme della propaganda politica nel Due e Trecento, ed. by P. Cammarosano, Proceedings of the Congress of Trieste, Trieste, March 2-5, 1993, Roma, École Française de Rome, p. 85-110. WEINFURTER, Stefan, 2000, "Friedrich II. staufischer Weltkaiser", in Virtuosen der Macht. Herrschaft und Charisma von Perikles bis Mao, ed. by W. Nippel, München, Beck, p. 72-88. KelLy, Samantha, 2003, The New Salomon. Robert of Naples (1309-1343) and FourteenthCentury Kingship, Leiden-Boston, Brill, XVIII-344 p. ANDENNA, Giancarlo, 2006, "Dalla legittimazione alla sacralizzazione della conquista (1042-1140)", in I caratteri originari della conquista normanna. Diversità e identità nel Mezzogiorno (1030-1130), Proceedings of the 16th Giornate Normanno-Sveve, Bari, October 5-8, 2004, Bari, Adda, p. 371-406.
} 
Anyway, let us begin with the Normans. ${ }^{8}$ In their images we can find the king pictured in connection with figures and symbols related with the sacred sphere like Christ, the Virgin, the angels, Saint Nicolas, the blessing hand of God, or the symbol of the Cross; however, they express only a very generic sense of sacrality. Certainly, in the little plaque from the ciborium of the Basilica of San Nicola in Bari (Fig. 1) Roger II is depicted while Saint Nicolas blesses him on his crown and in this way the imprimatur of the Saint to his power is underlined. But we cannot precisely talk about representation of a Deo coronatus concept.
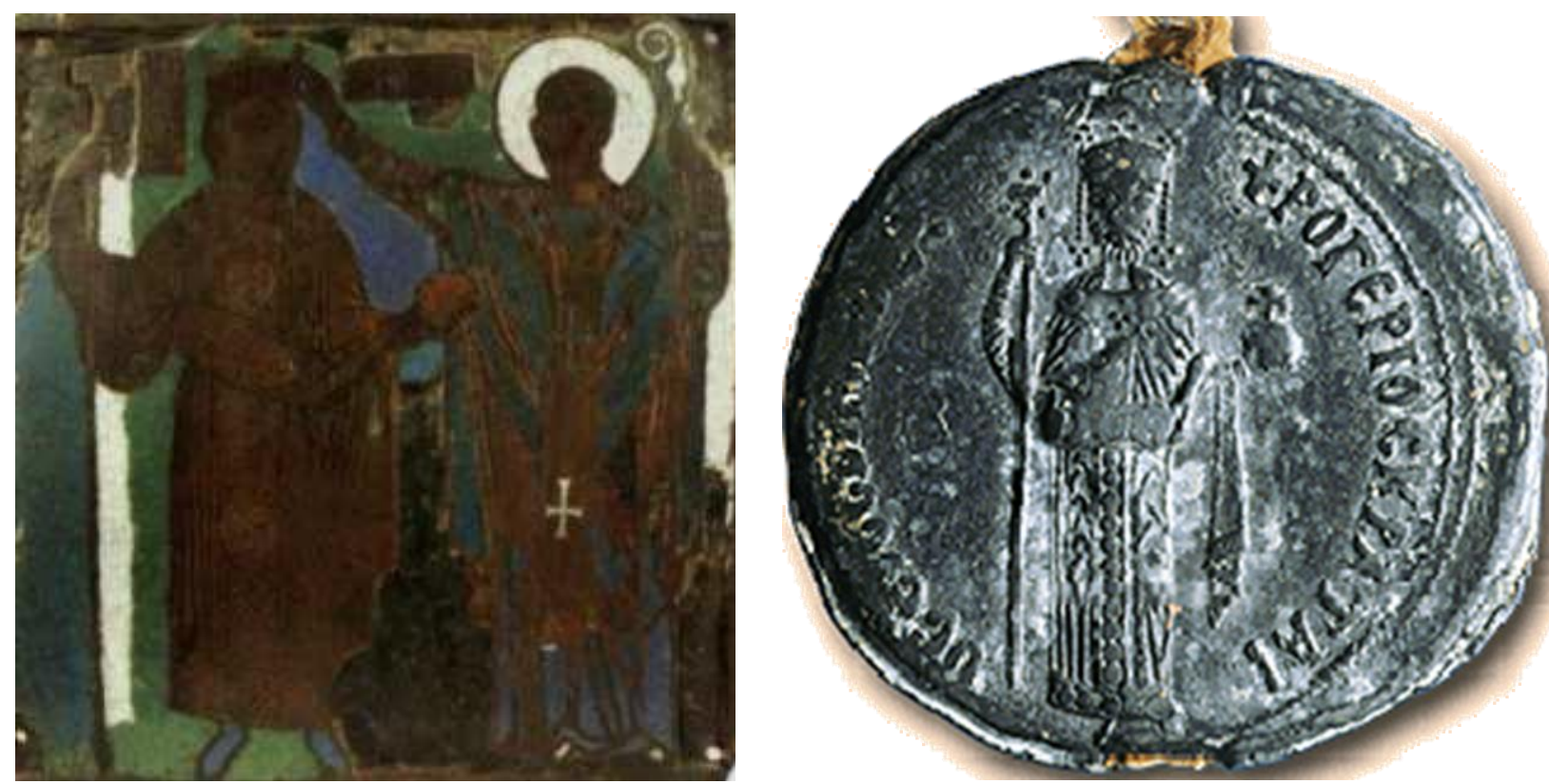

Fig. 1. Saint Nicolas blesses Roger II. Bari, Museum of the Basilica of San Nicola. Fig. 2. Bull of Roger II. Ariano Irpino (Avellino), Museum of Civiltà Normanna.

A bit more explicit in this sense is the royal bull (Fig. 2) adopted by these kings. Here, on one side is represented the ruler, and on the other the image of Christ with the inscription "ROGERIVS DEI GRACIA SICILIE CALABRIE APVLIE REX", underlining to some extent the divine origin of the monarchic power. This concept finds its complete explication in only two representations: the mosaic of the church of Santa Maria dell'Ammiraglio in Palermo and that of

\footnotetext{
${ }^{8}$ Here I am following: VAGNONI, Mirko, 2011, "Problemi di legittimazione regia: «Imitatio Byzantii»", in Il papato e $i$ Normanni. Temporale e spirituale in età normanna, ed. by E. D'Angelo, and C. Leonardi, Proceeding of the Congress, Ariano Irpino, December 6-7, 2007, Firenze, SISMEL, p. 175-190. IDEM, 2012, "Rex et sacerdos e christomimetes. Alcune considerazioni sulla sacralità dei re normanni di Sicilia", Mediaeval Sophia. Studi e ricerche sui saperi medievali, $\mathrm{n}^{\circ}$ 6, 2, http://www.mediaevalsophia.net, p. 268-284. IDEM, 2012, "Evocazioni davidiche nella regalità di Guglielmo II di Sicilia", in Hagiologica. Studi per Réginald Grégoire, ed. by A. Bartolomei Romagnoli, U. Paoli, and P. Piatti, Fabriano, Monastero San Silvestro Abate, p. 771-788. IDEM, 2012, Le rappresentazioni del potere. La sacralità regia dei Normanni di Sicilia: un mito?, intr. of J.-M. Martin, Bari, Caratteri Mobili, 140 p. IDEM, 2014 "I re normanni di Sicilia e i loro diplomi. Elementi di sacralità regia", in Auctor et auctoritas in Latinis Medii Aevi litteris, ed. by E. D'Angelo, Proceedings of the 6th Congress of Internationales Mittellateiner Komitee, Napoli-Benevento, November, 10-14, 2010, Firenze, SISMEL, in press.
} 
the cathedral of Santa Maria la Nuova in Monreale, where Christ is depicted crowning Roger II and William II, respectively.

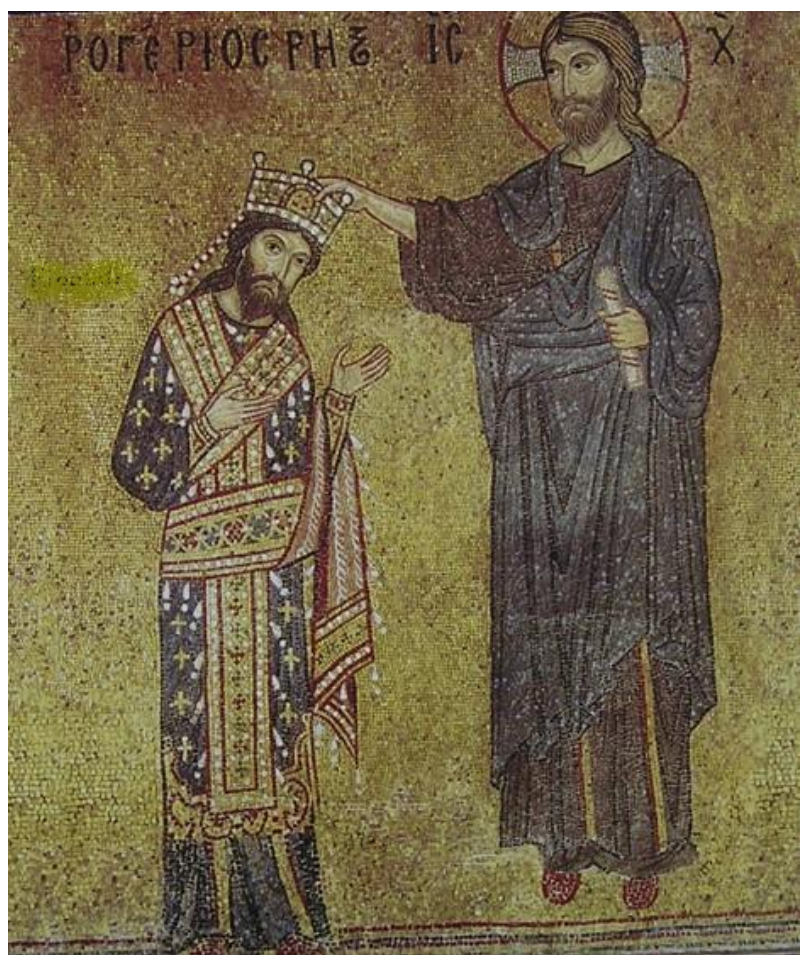

Fig. 3. Christ crowns Roger II. Palermo, Church of Santa Maria dell'Ammiraglio.

Regarding the first image (Fig. 3), Ernst Kitzinger has also proposed interpreting it as an expression of the identification between the king and the Messiah and of the Christic and sacerdotal character of the Roger's power: an absolute sacred power rising from the temporal into the spiritual sphere. Following Kitzinger, this concept would be expressed by the similarity of Roger's face to that of Christ.

This interpretation is dubious: the similarity of the two faces is not significant. The medieval portrait, in general, is typological, and we cannot assume that it was intended to be an accurate physical likeness of the subject, as in our modern sense. Usually every subject has the same somatic characteristics, and individuals are distinguished from each other by different hair and beards, as well as by specific clothes and symbolic elements. If in fact the mouth, nose, cheekbones, and eyes of the two figures are very similar, it is because these are the same facial characteristics that we can find in all the subjects depicted in the church. Evidently, this was the craftsman's way of reproducing the human face, and it has no ideological meaning.

Certainly, specific similarities can be found in the style of the hair and beard but, in actuality there are more differences: for example, the colors are a bit different, and likewise the shapes of the beards are a bit different; moreover, Christ has greater dimensions and $\mathrm{He}$ is placed in a higher position than Roger (this is a way to underline greater importance of one subject in medieval art); $\mathrm{He}$ wears completely different clothes, and, finally, $\mathrm{He}$ is characterized by the aureole whereas Roger is not. The status of the two figures is really different, and 
my conclusion is that, on the basis of this mosaic, there is not a Christ-mimetic or a sacerdotal intent. It shows only the concept of king as a Deo coronatus.

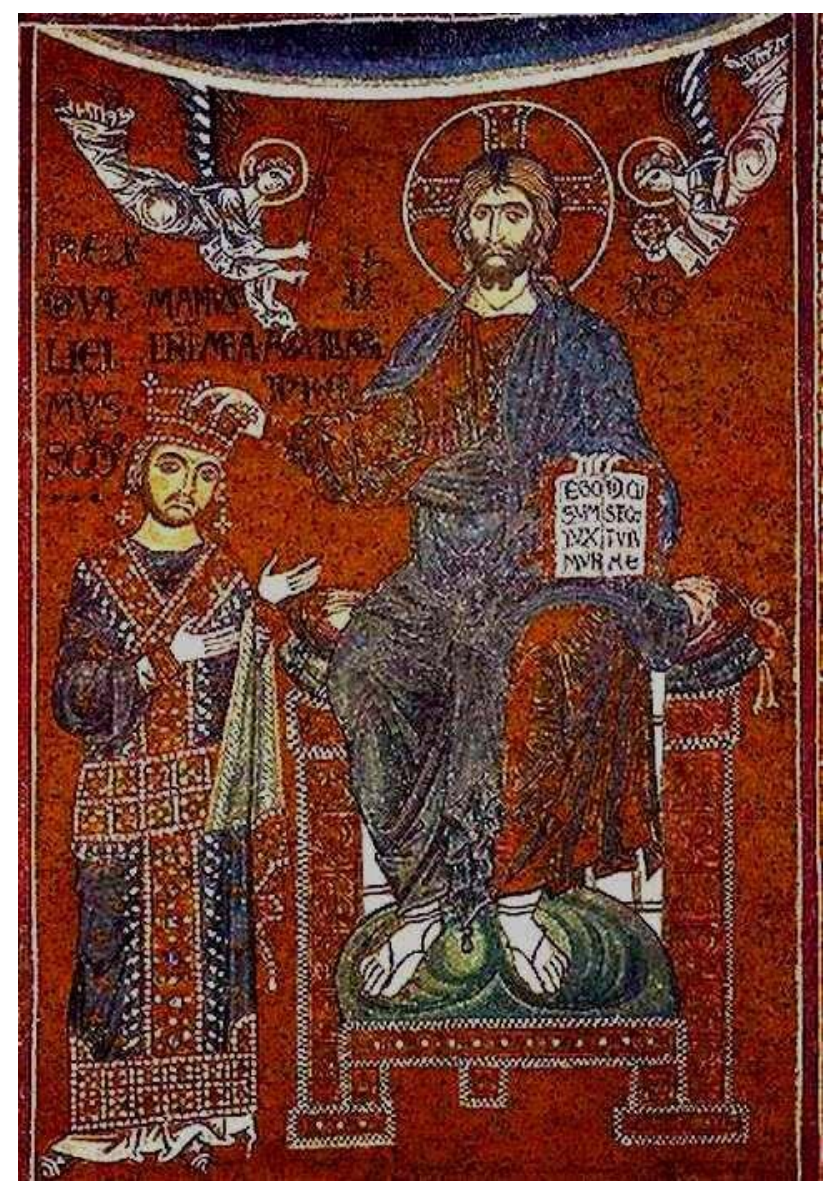

Fig. 4. Christ crowns William II. Monreale (Palermo), Cathedral of Santa Maria la Nuova.

Regarding the second mosaic (Fig. 4), Eve Borsook considered it as resembling a genealogical tree of the biblical kings of Jerusalem and, for this reason, she talked about William II as an heir of David, interpreting his power in a eschatological and messianic way.

I likewise disagree with this position. In fact, nothing explains the decoration of the presbytery (where the mosaic is placed) in this sense, and the biblical kings of Jerusalem are not in fact in a close relationship with the picture of William. Moreover, just as in the mosaic of the Martorana, there is a complete iconographic distinction between the king and the figures of sacred and religious sphere, as well as between him and the image of Christ. Again, my conclusion is that we can speak only about a representation of the ideological concept of king as a Deo coronatus underlined by the presence of saints and biblical figures around the king. We cannot speak about a representation of eschatological and messianic intent.

Comparing the iconographic sources with the textual ones, we can achieve very similar results. In fact, in the Ordo coronationis used for the coronation of Roger II, in the homilies addressed to him by Filagato Ceramide, in the verse of Eugenio of Palermo for William I, in the history written by Alexander of Telese, as well as in the prologue of the so-called Assise of Ariano, and in the royal 
diplomas, we can find references only to the concept of king as a Deo coronatus and nothing about the model of messianic and sacerdotal king that previous scholars have applied to the Norman rulers.

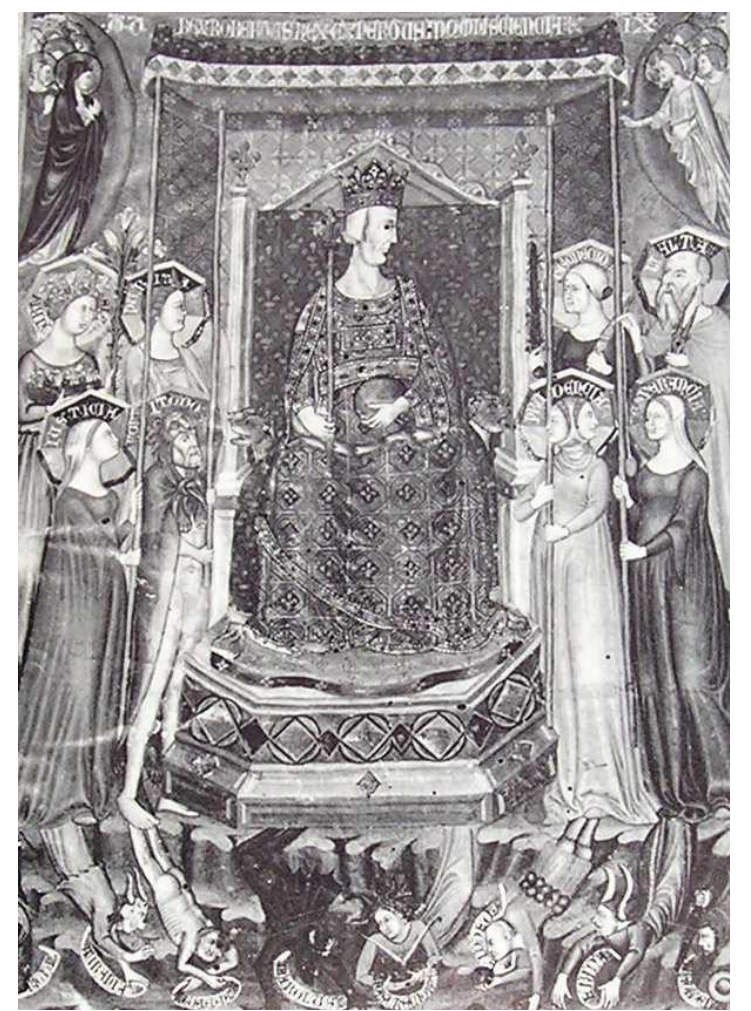

Fig. 5. Cristoforo Orimina, Robert of Anjou. Miniature of "Bible of Malines". Leuven, Bibliotheek Faculteit Theologie.

\section{Robert of Anjou}

As I have already noted, royal sacrality disappears in the iconography of Swabian and Aragonese kings and the first two Charles of Anjou (apart some depictions of the Cross), and it comes back in the representations of Robert of Anjou (1309-1343), but in very different forms and in a very generic manner. ${ }^{9}$ In fact, this king is never depicted as being crowned by God or Christ but only in generic acts of receiving divine blessing, as in the miniature of Cristoforo Orimina in the so-called Bible of Malines (Fig. 5) or of merely displaying devotion towards Christ and saints, as in the fresco of Lello of Orvieto in the convent of Santa Chiara in Napoli (Fig. 6), in the painting of the Master of the Tempere Francescane (Fig. 7), as well as in the painting of the Master of Giovanni Barrile (Fig. 8). Moreover, many details explain the difference of status between the king and these latter: for example Robert has small dimensions, and

\footnotetext{
${ }^{9}$ Here I am following: VAGNONI, Mirko, 2008, Raffigurazioni regie ed ideologie politiche. I sovrani di Sicilia dal 1130 al 1343, Ph.D. Thesis, University of Florence, unpublished. IDEM, 2009, "L'immagine dei re di Sicilia", in M. BusSAGLI - G. M. CANTARELla - F. Delle DonNE - L. RUSSO - M. VAGNONI, Svevi, Angioini, Aragonesi. Alle origini delle Due Sicilie, Udine, Magnus, p. 138-163. IDEM, 2009, "Una nota sulla regalità sacra di Roberto d'Angiò alla luce della ricerca iconografica", Archivio Storico Italiano, n 167, 2, p. 253-268.
} 
his face is depicted in profile, without an aureole, and with a strong character of portraiture underlining his human nature.

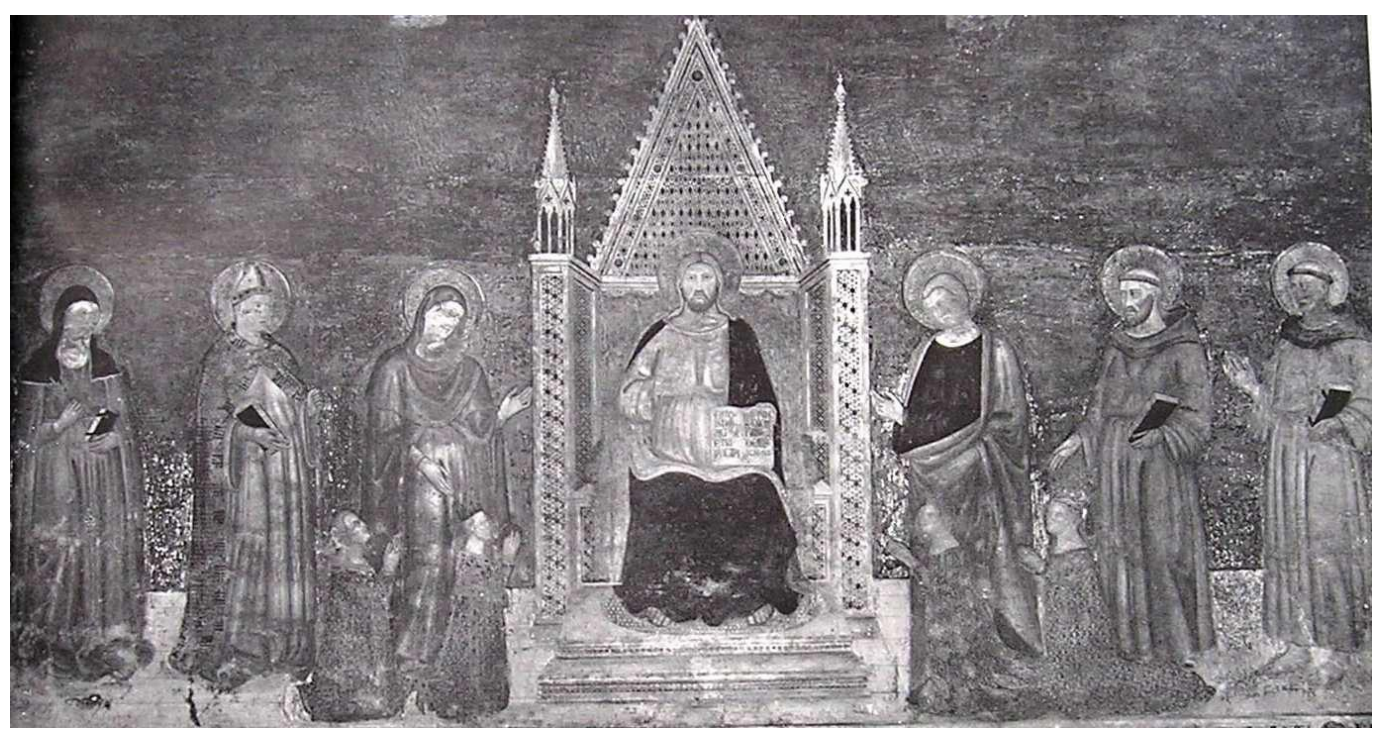

Fig. 6. Lello of Orvieto, Christ, saints, and Angevin royal family.

Napoli, Convent of Santa Chiara.
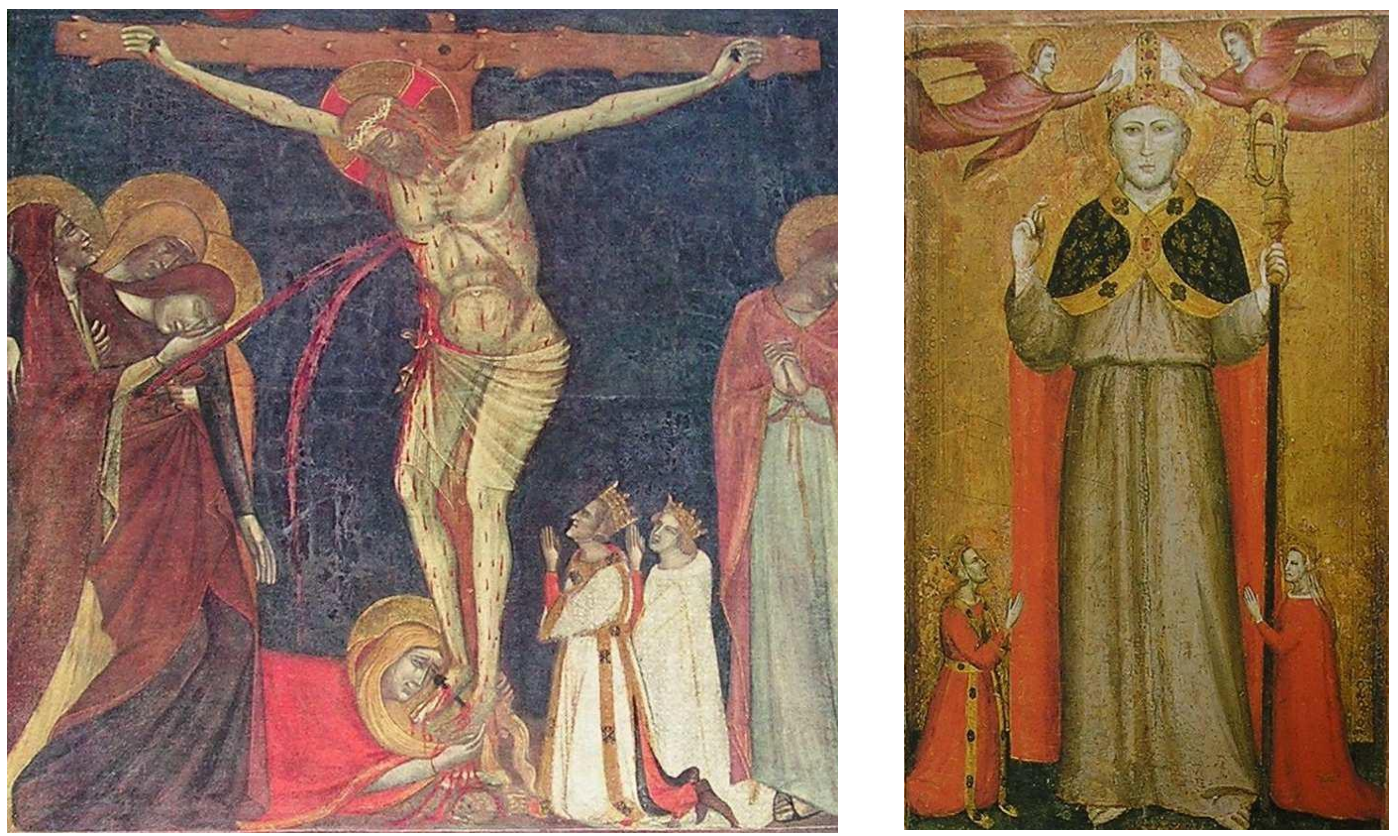

Fig. 7. Master of the Tempere Francescane, The Crucifixion, Robert of Anjou, and Sancia of Mallorca. Private collection.

Fig. 8. Master of Giovanni Barrile, Saint Ludwig of Toulouse, Robert of Anjou, and Sancia of Mallorca. Aix-en-Provence, Musée Granet.

In the same way, while he is sculpted wearing the Franciscan habit in his monumental tomb realized by Giovanni and Pacio Bertini in the church of the convent of Santa Chiara in Napoli (Fig. 9), this depiction is not meant to express his sacerdotal character but only his devotion; and, even if, in the painting of Simone Martini (Fig. 10), he is crowned by Saint Ludwig of Toulouse, we ought to consider that the Saint was also the older brother of Robert and the legitimate 
heir to the Crown before his religious vocation. Thus, the picture does not necessarily explain the sacrality of Robert and surely does not depict him in a sacerdotal or Christ-mimetic manner, nor even, as a Deo coronatus.

Although the presence of sacral and religious elements in his iconography (I would also recall the symbol of the Cross), Robert's sacrality is expressed in a very generic way and without revealing the highly sacralizing concepts generally identified by historians. It is notable that a confirmation in this sense also appears in some textual sources such as the Ordo coronationis and some sermons celebrating the king, and this connection merits further investigation.
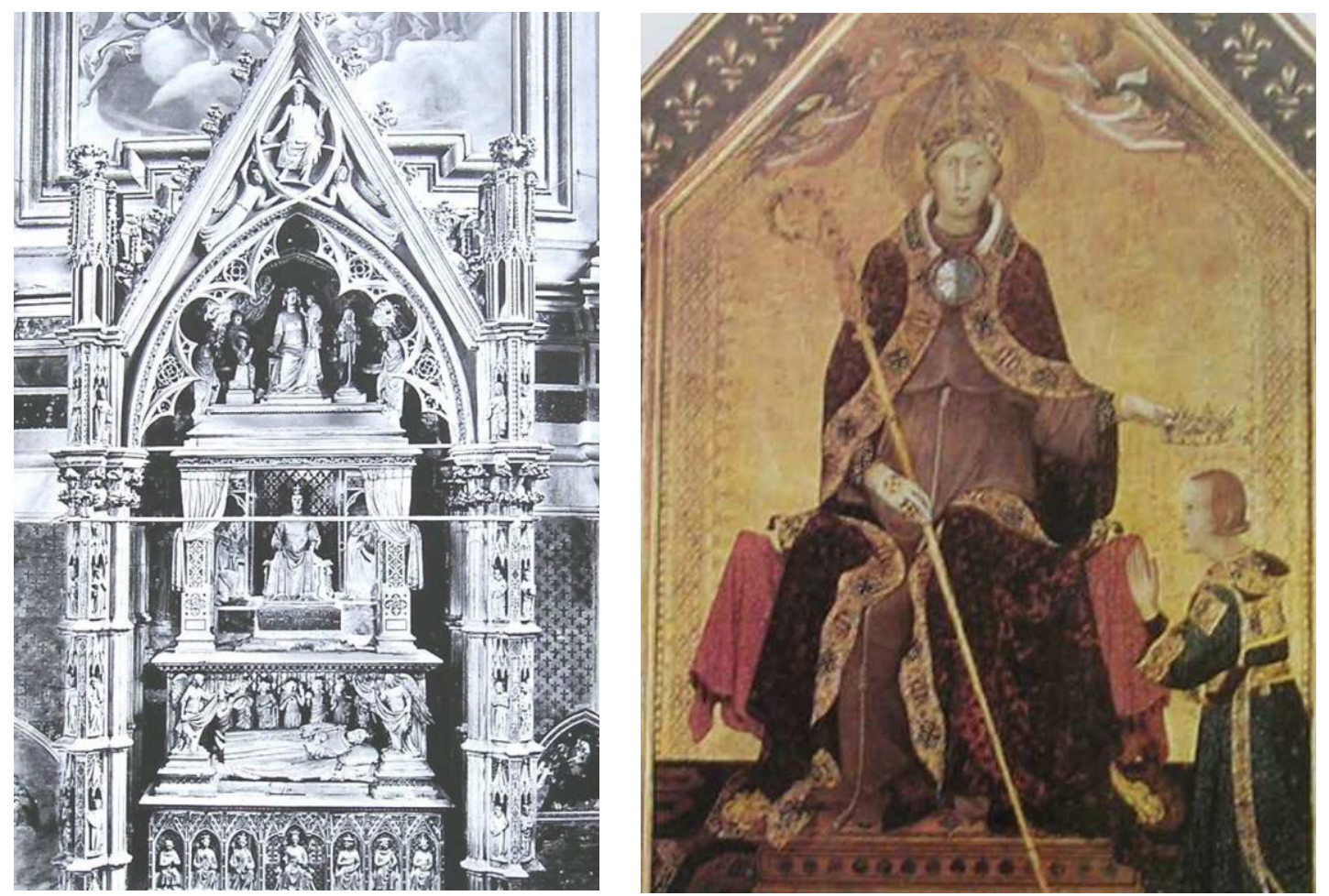

Fig. 9. Giovanni, and Pacio Bertini, Monumental tomb of Robert of Anjou.

Napoli, Church of the Convent of Santa Chiara.

Fig. 10. Simone Martini, Saint Ludwig of Toulouse crowns Robert of Anjou. Napoli, Museum of Capodimonte.

\section{Frederick II}

I wish to conclude with some considerations about the sacrality of Frederick II and particularly about his divine and messianic character. ${ }^{10}$ Even if similar

\footnotetext{
${ }^{10}$ Here I am following: VAGNONI, Mirko, 2004, Federico II allo specchio. Analisi iconografica e politico-funzionale delle sue raffigurazioni, Degree Thesis, University of Siena, unpublished. IDEM, 2006, "La legittimità e la sacralità imperiale di Federico II di Svevia", Tabulae. Del Centro Studi Federiciani, n ${ }^{\circ}$ 18, 1, p. 127-169 (republished in 2012, Eikón/Imago, n ${ }^{\circ}$ 1, 2, http://capire.es/eikonimago/, p. 49-72). IDEM, 2006, "Il significato politico delle caratteristiche iconografiche di Federico II di Svevia", Iconographica. Rivista di iconografia medievale $e$ moderna, $\mathrm{n}^{\circ}$ 5, p. 64-75. IDEM, 2008, "Caesar semper Augustus. Un aspetto dell'iconografia di Federico II di Svevia", Mediaeval Sophia. Studi e ricerche sui saperi medievali, $\mathrm{n}^{\circ} 2,1$, http://www.mediaevalsophia.net, p. 142-161. IDEM, 2009, "Lex animata in terris. Sulla sacralità
} 
considerations had already been presented in previous works, the sacrality of Frederick II is particularly emphasised in the Kaiser Friedrich II of Ernst Kantorowicz. The idea of a sacred king, perhaps influenced by the previously mentioned Das Heilige of Rudolf Otto, was particularly functional with regard to the image of an absolute sovereign that Kantorowicz outlined. Indeed, Kantorowicz often talked about the divine and messianic, as well as the angelic and priestly character of Frederick II.

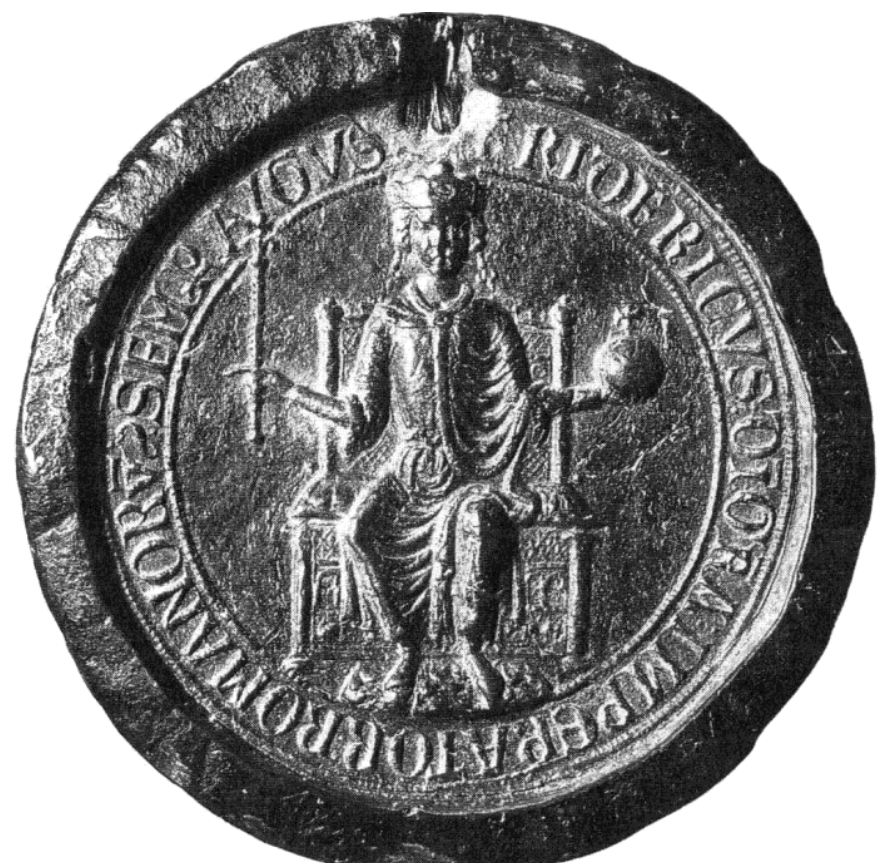

Fig. 11. Imperial seal of Frederick II. München, Bayerische Hauptstaatarchiv.

Though Kantorowicz's book on Frederick II has been criticized, and his conclusions have been revised by other scholars, his interpretation of the sacrality of Frederick II, in general, has nevertheless been widely accepted by historians, and even in more recent works we can find consideration, though with a less emphatic tone, of a Frederick II compared to and equated to God and Christ.

On the contrary, in my previous work on the analysis of the official images of Frederick II in sphragistics, numismatics, glyptic, jewelry, sculpture, painting and miniature, I have found no explicit elements regarding this pattern of sacrality. Indeed, in his iconographic language the act of crowning or blessing by Christ or by the hand of God disappears; and likewise there is no longer the presence of saints, angels or religious and sacred symbols. In other words, in his

di Federico II di Svevia”, Mediaeval Sophia. Studi e ricerche sui saperi medievali, $\mathrm{n}^{\circ} 3,1$, http://www.mediaevalsophia.net, p. 101-118 (republished in 2012 De Medio Aevo, $\mathrm{n}^{\circ}$ 1, 1, http://capire.es/eikonimago/, p. 47-66). IDEM, 2013, "L'immagine di Federico II di Svevia. Un riesame", Eikón/Imago, $\mathrm{n}^{\circ}$ 2, 1, http://capire.es/eikonimago/, p. 49-68. And in particular VAGNONI, Mirko, 2013, "Divus Fridericus? Alcune annotazioni sul carattere divino e messianico di Federico II di Svevia", Mediaeval Sophia. Studi e ricerche sui saperi medievali, $\mathrm{n}^{\circ} 7,1$, http://www.mediaevalsophia.net, p. 140-156. 
iconography there are no overt elements which indicate a divine and messianic, nor an angelic and priestly character of his image.
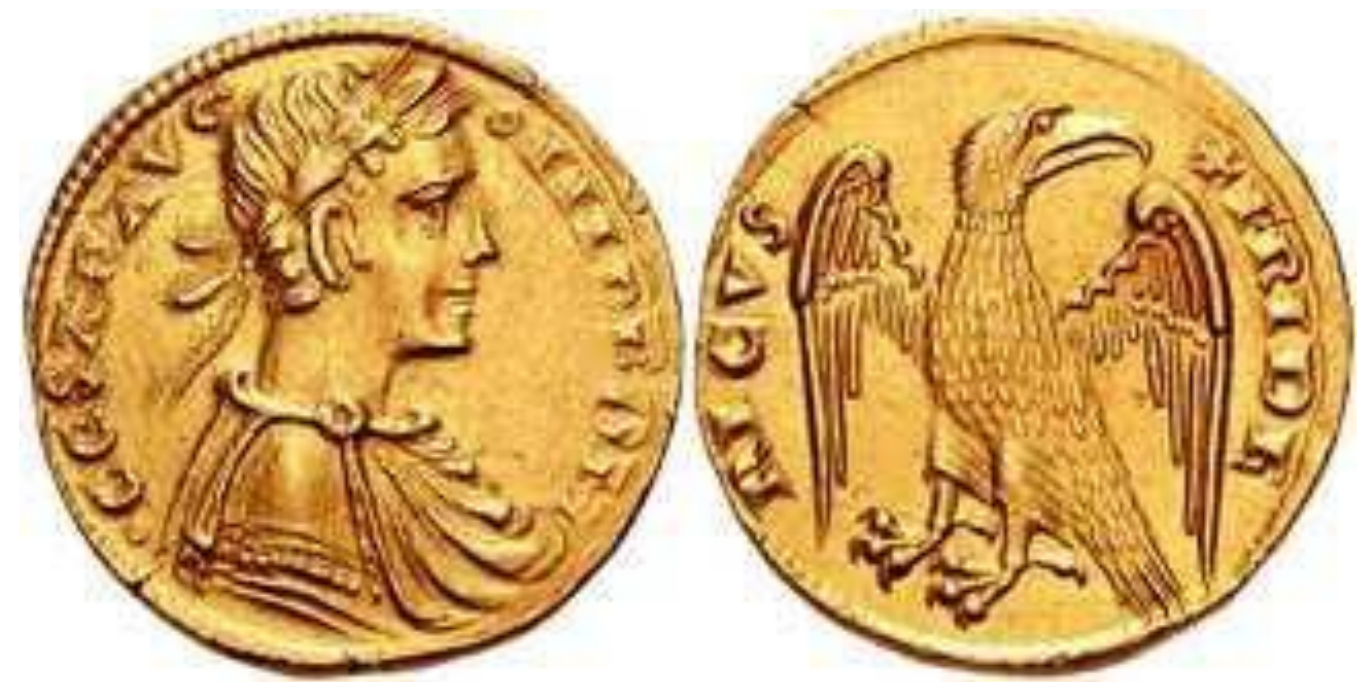

Fig. 12. Augustale. Napoli, Museo Archeologico Nazionale.

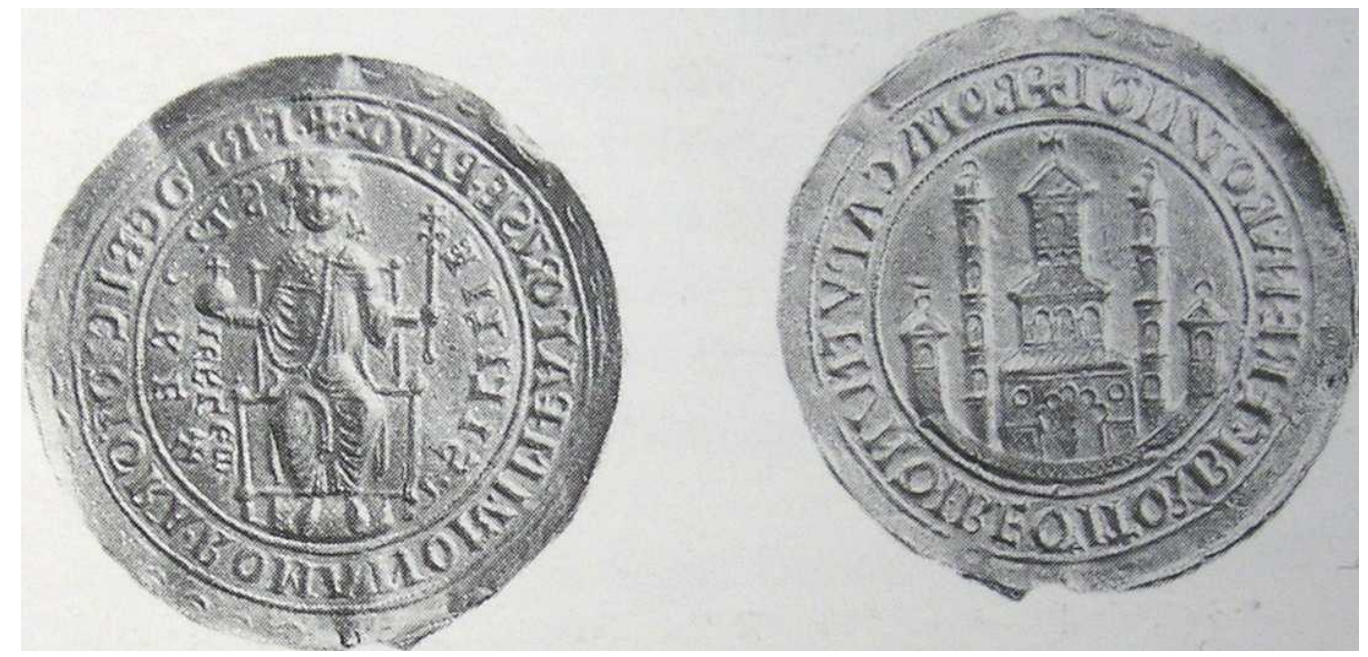

Fig. 13. Imperial bull of Frederick II. Karlsruhe, Generallandesarchiv

Other aspects, other representations of power, have more importance for the Swabian emperor: for example his connection with the Holy Roman Empire, expressed by the exchange of the Norman bull for the traditional German seal (Fig. 11) and in particular with the ancient Roman Empire, expressed by the depiction of the king in the typical ancient Roman imperial dress and with Roman symbols of power, or by the use of stereotypical depiction of the city of Rome and the imperial eagle, as we can see in the famous Augustale coin and in the imperial bull (Figs. 12 and 13), or the depiction of the sovereign as source of law and Lex animata in Terris, as in the sculpture of the Arch of Capua (Fig. 14). 


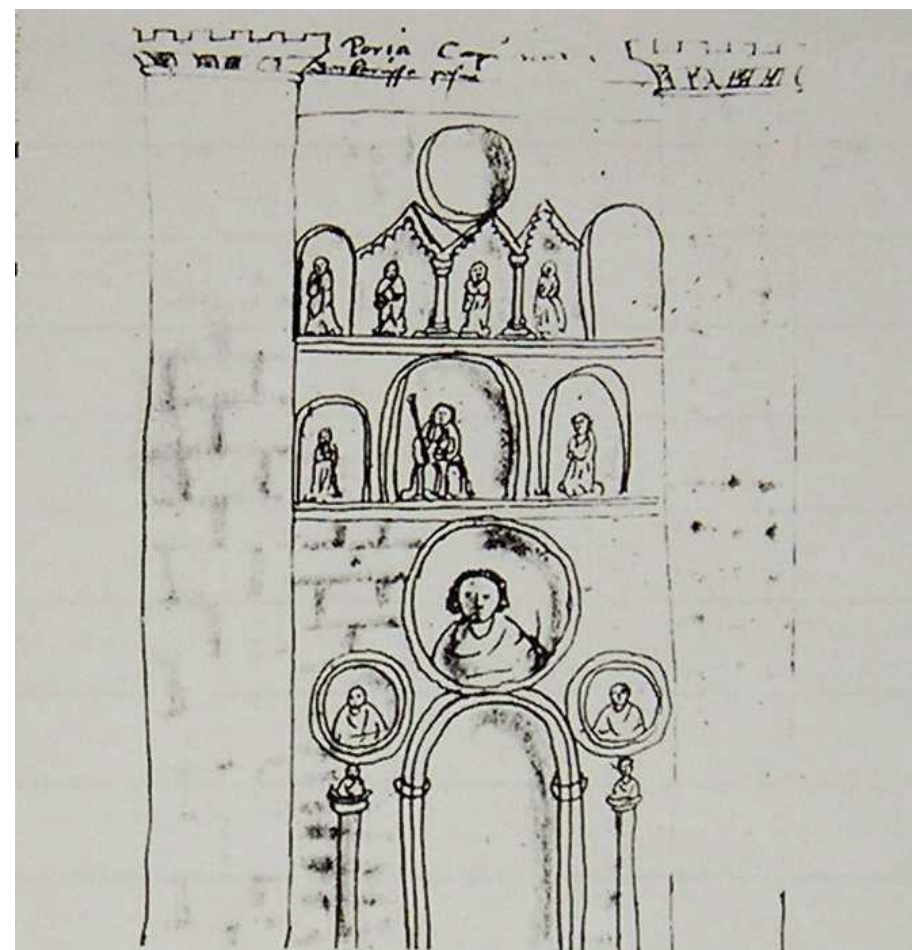

Fig. 14. Drawing of the Arch of Capua. Wien, Österreichische Nationalbibliothek.

In the last few years historians have produced a number of new studies dealing with representations of Frederick II. For my own part, I have recently reevaluated both dubious and genuine likenesses of the king present in sphragistics, numismatics, glyptic, jewelry, sculpture, painting and miniature. In so doing, I have substantially decreased the number of the portraits of Frederick II which we know to have been produced both in his court and as a result of his own initiative. Even despite these new researches, it is nevertheless clear that, in terms of visual representations, Frederick preferred to ascribe Roman, imperial, legal qualities himself and his rule, rather than messianic or sacerdotal characteristics. It is, however, rather curious, because the study of written sources produces one result, whereas the iconographic analysis produces another. Did Frederick II really want to give these different images of himself?

To answer to this question, I have decided to compare my iconographic results with the texts which have been quoted by historians as particularly important sources for the interpretation of Frederick's sacrality, in order to look for direct, explicit and decisive elements of it. First it is important to understand which type of sources the historiography has generally privileged in this regard.

We can identify six different types, namely sources produced after the death of Frederick II; sources produced outside the court and in an enemy context (for example the papal court or the cities of northern Italy); sources produced outside the court but in a friendly context (for example in Swabian or Ghibelline areas); sources for which we do not know the origin, time, audience, or purpose of their production; sources produced at the court and to celebrate the king but with a private character (for example letters between courtiers or poems written by members of the court but without the imperial order); and sources produced at the court with an official point of view and in the name of Frederick II. 
Obviously, only the last type can be useful for this kind of work, and thus only these sources must be analyzed. Finally, a consideration about the methodology of my analysis: my opinion is that historians, studying these sources, have overemphasised, with regard to the sacred sense, the meaning of elements that are not necessary linked with sacrality. I think that the meaning of symbolic elements (that, for their nature, are open to different interpretations) must be given by the text. In other words, I think that our task is to find in these sources clear and explicit references to the divine and messianic, as well as to the angelic and priestly character of Frederick II, in order not to force the real meaning of these texts into anachronistic and preconceived schemes.

This is what I have done in my research, and I have reached surprising conclusions. First of all, despite the very prolific production of Frederick II's court, there are very few extant documents (only 25), and in general they do not really reveal much about the king's alleged sacrality. Yes, we can identify a relationship between the emperor and God and Christ by the fact, for example, that the king's power emanates from them, and that they have elected and crowned him king. Likewise, Frederick says that in legal and judicial actions he is inspired by God. However, the relationships between the ruler and the divine is never explicated in sense of identification between the king and the deity and even if, sometimes, what the emperor does is presented as an action of God, this is because Frederick, humbly, considers himself to be a mere tool of God. The main intent of the text, then, is to celebrate the Lord more than the king. Moreover, if at other times Frederick has a relationship, for example, with the angels, he does not, in any case, identify himself with them at all.

If Frederick is celebrated as lord of the whole world and even of the natural elements, this is done without giving him a divine character, and it is included in a monotheistic context that excluded the possibility of interpreting Frederick as a deity. If the emperor, on rare occasions, uses the adjective divus for himself, this is not necessarily because he considers himself an idol but in order to express his relationship with the sphere of God. Moreover, we can find nothing about an eschatological and messianic interpretation of Frederick like the emperor of the last time or like the new leader who, following the thought of Joachim of Fiore, would renew the Christendom before the arrival of the Antichrist.

Other times the text has a completely devotional sense, and even the simple celebration of the emperor does not find space. Moreover, if Frederick sometimes has a relationship with King David, it is not to underline his messianic and priestly character (in the way of a rex et sacerdos). Indeed, we can often find in the texts explicit considerations of the authority of the emperor only in the temporal sphere of the power, and, concerning his functions in the ecclesiastic area, there are references only to his military protection (or, eventually, to his patronage) of the Christian faith and the Church.

Other times Frederick, quoting passages from the Bible regarding Christ or even the words of the Redeemer Himself, has a relationship, in some way, with the Messiah, but there is no reason to presume that this was blasphemic. Christ is only taken as a model. Modelling oneself on Christ is also particularly useful, depending on the sense of the text, for underlining the good behaviour of the 
emperor, his devotion, his faith and his respect for and submission to the pope and the Church, as well as, in other situations, the perfidy and the wickedness of the pope in his actions against Frederick II. Moreover, these messianic relationships are sometimes included in a context that mainly celebrates the Imperial and Caesarean aspect of Frederick II's power.

In the end, my general opinion is that in his official representation Frederick does not identify himself with God or Christ, nor with an angel or a priest (at least not explicitly and not in the tone generally proposed by historiography). These interpretations are forcing the real meaning of the sources too much. Thus my conclusion is that the concepts of imago Dei, christomimetes and rex et sacerdos appear inadequate for him, and his sacrality appears in fact rather underpowered and reduced in comparison with what historians have generally proposed. Perhaps, considering the iconographic evidences, even its weight in Frederick II's kingship should be reevaluated, but this is another question.

\section{Conclusions}

If the concept of king as a Deo coronatus is present sometimes in the sacrality of the kings of Sicily, those of king as imago Dei, christomimetes and rex et sacerdos are completely absent. Is this type of sacrality a specific characteristic of the kings of Sicily? Or, is this a constant for the whole Middle Ages? Or, even, is this a cultural transfer from a specific Latin, Greek or Arabic kingdom? Maybe a comparison with the royal sacrality of the other Euro-Mediterranean kings of the Middle Ages could help us in answering these questions.

\section{Bibliography}

$* * * * *$

ANDENNA, Giancarlo, 2006, "Dalla legittimazione alla sacralizzazione della conquista (1042-1140)", in I caratteri originari della conquista normanna. Diversità e identità nel Mezzogiorno (1030-1130), Proceedings of the 16th Giornate Normanno-Sveve, Bari, October 5-8, 2004, Bari, Adda, p. 371-406.

BION, Wilfred Ruprecht, 1971, "Dinamiche di gruppo", ora in IDEM, Esperienze nei gruppi e altri saggi, It. ed., Roma, Armando (but original ed. London, 1961), p. 149-202.

BLOCH, Marc, 1989, I re taumaturghi. Studi sul carattere sovrannaturale attribuito alla potenza dei re particolarmente in Francia e in Inghilterra, intr. of J. Le Goff, Ricordo di Marc Bloch of L. Febvre, It. ed., Torino, Einaudi (but original ed. Paris, 1924), LXVIII-424 p.

BOYER, Jean-Paul, 1994, "La «foi monarchique»: royaume de Sicile et Provence (mi-XIII - mi-XIV siècle)", in Le forme della propaganda politica nel Due e Trecento, ed. by P. Cammarosano, Proceedings of the Congress of Trieste, Trieste, March 2-5, 1993, Roma, École Française de Rome, p. 85-110.

CANTARElla, Glauco Maria, 2005, "Divagazioni preliminari", in "C'era una volta un re... ». Aspetti e momenti della regalità, ed. by G. Isabella, 
Proceedings of the Seminar of Bologna, Bologna, December 17-18, 2003, Bologna, CLUEB, p. 9-24.

CANTARElla, Glauco Maria, 1988, La Sicilia e i Normanni. Le fonti del mito, intr. of O. Capitani, Bologna, Pàtron, 197 p.

Cantarella, Glauco Maria, 2002, "Le basi concettuali del potere", in Per me reges regnant. La regalità sacra nell'Europa medievale, ed. by F. Cardini, and M. Saltarelli, Rimini-Siena, Cantagalli-il Cerchio, p. 193-208.

CANTARELlA, Glauco Maria, 2003, "Qualche idea sulla sacralità regale alla luce delle recenti ricerche: itinerari e interrogativi”, Studi Medievali, s. III, nº 44, p. 911-927.

ELIAS, Norbert, 1980, La società di corte, It. ed., intr. of A. Tenenti, Bologna, il Mulino (but original ed. Darmstadt-Neuwied, 1969), $382 \mathrm{p}$.

Freud, Sigmund, 2013, Psicologie delle masse e analisi dell'io, It. ed., ed. by D. Tarizzo, Torino, Einaudi (but original ed. Leipzig, 1921), LI-92 p.

KANTOROWICZ, Ernst, 2000, Federico II imperatore, It. ed., Milano, Garzanti (but original ed. Berlin, 1927-1931), $791 \mathrm{p}$.

KeLly, Samantha, 2003, The New Salomon. Robert of Naples (1309-1343) and Fourteenth-Century Kingship, Leiden-Boston, Brill, XVIII-344 p.

KitZINGER, Ernst, 1950, "On the Portrait of Roger II in the Martorana in Palermo", Proporzioni. Studi di Storia dell'Arte, n 3, p. 30-35.

Oтто, Rudolf, 1966, Il sacro. L'irrazionale nell'idea del divino e la sua relazione al razionale, It. ed., Milano, Feltrinelli (but original ed. Breslau, 1917), $192 \mathrm{p}$.

SCHALLER, Hans-Martin, 1974, "Die Kaiseridee Friedrichs II.", in Probleme um Friedrich II., ed. by J. Fleckenstein, Sigmaringen, Thorbecke, p. 109-134.

SCHRAMM, Percy Ernst, 1928, Die deutschen Kaiser und Könige in Bildern ihrer Zeit. Bis zur Mitte 12. Jahrhunderts (751-1152), Berlin-Leipzig, Teubner, 2 vol.

SCHRAMM, Percy Ernst, 1929, Kaiser, Rom und Renovatio. Studien und Texte zur Geschichte des römischen Erneuerungsgedankens vom Ende des karolingischen Reiches bis zum Investiturstreit, Leipzig, Wissenschaftliche Buchgesellschaft, $490 \mathrm{p}$.

VAGNONI, Mirko, 2008, "Caesar semper Augustus. Un aspetto dell'iconografia di Federico II di Svevia", Mediaeval Sophia. Studi e ricerche sui saperi medievali, $\mathrm{n}^{\circ} 2,1$, http://www.mediaevalsophia.net, p. 142-161.

VAGNONI, Mirko, 2013, "Divus Fridericus? Alcune annotazioni sul carattere divino e messianico di Federico II di Svevia", Mediaeval Sophia. Studi e ricerche sui saperi medievali, $\mathrm{n}^{\circ} 7,1$, http://www.mediaevalsophia.net, $\mathrm{p}$. 140-156.

VAGNONI, Mirko, 2012, "Evocazioni davidiche nella regalità di Guglielmo II di Sicilia", in Hagiologica. Studi per Réginald Grégoire, ed. by A. Bartolomei Romagnoli, U. Paoli, and P. Piatti, Fabriano, Monastero San Silvestro Abate, p. 771-788.

VAGNONI, Mirko, 2004, Federico II allo specchio. Analisi iconografica e politico-funzionale delle sue raffigurazioni, Degree Thesis, University of Siena, unpublished. 
VAGNONI, Mirko, 2006, "Il significato politico delle caratteristiche iconografiche di Federico II di Svevia”, Iconographica. Rivista di iconografia medievale e moderna, $\mathrm{n}^{\circ} 5$, p. 64-75.

VAGNONI, Mirko, 2014 "I re normanni di Sicilia e i loro diplomi. Elementi di sacralità regia", in Auctor et auctoritas in Latinis Medii Aevi litteris, ed. by E. D'Angelo, Proceedings of the 6th Congress of Internationales Mittellateiner Komitee, Napoli-Benevento, November, 10-14, 2010, Firenze, SISMEL, in press.

VAGNONI, Mirko, 2006, "La legittimità e la sacralità imperiale di Federico II di Svevia", Tabulae. Del Centro Studi Federiciani, $\mathrm{n}^{\circ}$ 18, 1, p. 127-169 (republished in 2012, Eikón/Imago, n ${ }^{\circ}$ 1, 2, http://capire.es/eikonimago/, p. 49-72).

VAGNONI, Mirko, 2012, Le rappresentazioni del potere. La sacralità regia dei Normanni di Sicilia: un mito?, intr. of J.-M. Martin, Bari, Caratteri Mobili, $140 \mathrm{p}$.

VAGNONI, Mirko, 2009, "Lex animata in terris. Sulla sacralità di Federico II di Svevia", Mediaeval Sophia. Studi e ricerche sui saperi medievali, $\mathrm{n}^{\circ} 3,1$, http://www.mediaevalsophia.net, p. 101-118 (republished in 2012 De Medio Aevo, $\mathrm{n}^{\circ}$ 1, 1, http://capire.es/eikonimago/, p. 47-66).

VAGNONI, Mirko, 2009, "L'immagine dei re di Sicilia", in M. BuSSAGLI - G. M. CANTARElla - F. Delle Donne - L. Russo - M. VAgnOni, Svevi, Angioini, Aragonesi. Alle origini delle Due Sicilie, Udine, Magnus, p. 138-163.

VAGNONI, Mirko, 2013, "L'immagine di Federico II di Svevia. Un riesame", Eikón/Imago, $\mathrm{n}^{\circ}$ 2, 1, http://capire.es/eikonimago/, p. 49-68.

VAGNONI, Mirko, 2011, "Problemi di legittimazione regia: «Imitatio Byzantii»", in Il papato e i Normanni. Temporale e spirituale in età normanna, ed. by E. D'Angelo, and C. Leonardi, Proceeding of the Congress, Ariano Irpino, December 6-7, 2007, Firenze, SISMEL, p. 175-190.

VAGNONI, Mirko, 2008, Raffigurazioni regie ed ideologie politiche. I sovrani di Sicilia dal 1130 al 1343, Ph.D. Thesis, University of Florence, unpublished.

VAGNONI, Mirko, 2012, "Rex et sacerdos e christomimetes. Alcune considerazioni sulla sacralità dei re normanni di Sicilia”, Mediaeval Sophia. Studi e ricerche sui saperi medievali, $\mathrm{n}^{\circ} 6,2$, http://www.mediaevalsophia.net, p. 268-284.

VAGNONI, Mirko, 2009, "Una nota sulla regalità sacra di Roberto d'Angiò alla luce della ricerca iconografica”, Archivio Storico Italiano, $\mathrm{n}^{\circ} 167,2$, p. 253268.

WEBER, Max, 1961, Economia e società, It. ed., intr. of P. Rossi, Milano, Edizioni di Comunità (but original ed. Tübingen, 1922), 2 vol.

WEINFURTER, Stefan, 2000, "Friedrich II. staufischer Weltkaiser", in Virtuosen der Macht. Herrschaft und Charisma von Perikles bis Mao, ed. by W. Nippel, München, Beck, p. 72-88. 